\title{
Wildfire Impact and the "Fire Paradox" in a Natural and Endemic Pine Forest Stand and Shrubland
}

\author{
José Ramón Arévalo ${ }^{1, *(1)}$ and Agustín Naranjo-Cigala ${ }^{2}(\mathbb{D}$ \\ 1 Department of Botany, Ecology and Plant Physiology, Universidad de La Laguna, 38206 La Laguna, \\ Islas Canarias, Spain \\ 2 Department of Geography, Universidad de Las Palmas de Gran Canaria, 35003 Las Palmas de Gran Canaria, \\ Islas Canarias, Spain; anaranjo@dgeo.ulpgc.es \\ * Correspondence: jarevalo@ull.edu.es; Tel.: +34-922-318-628
}

Received: 28 August 2018; Accepted: 9 November 2018; Published: 13 November 2018

check for updates

\begin{abstract}
Fire is a powerful force that has shaped forests for thousands of years. It also provokes widespread social concern due to possible economic damage, social effects, impact on homes and properties, and other social effects including fatalities. Regions with seasonal variations in aridity have a fire regime dependent on climate resulting from the role of precipitation and temperature in fire occurrence, implying a synchrony of fire occurrence at regional scale. This spatial and temporal variation of fire regimes regulates the structure, diversity, regeneration dynamics, and nutrient cycle of an area. In the Canary Islands, fires are recurrent in pine forests, although their occurrence in the same area more than once within a 20-year period is rare. The main aim of this work is to reveal, over a 50-year period, fire occurrence and impact on the Canary Islands and how the islands are immersed in a "fire paradox" — a process typical of protected areas, where fire suppression becomes one of the main aims of forest management.
\end{abstract}

Keywords: Canary Islands; fire paradox; fire suppression; Pinus canariensis forests

\section{Introduction}

Some of the most common disturbances of forest ecosystems are forest fires [1]. These fires are considered as old as forests themselves, even occurring before the presence of humans. This was demonstrated with charcoal studies, which found evidence of forest fires 390 million years ago [2]. Natural causes of forest fires can include lightning as one of the most common, but also volcanic activity, among others. Indeed, natural fires have a regular impact on forest ecosystems [3]. However, human fire activity is the primary cause of wildfires in populated areas [3]. These wildfires generate a powerful force for species to evolve and adapt to these ecological disturbances. Consequently, forest fires cannot be considered, in general, a non-natural disturbance. Indeed, they should be perceived more as an intrinsic process - part of the dynamics of the ecosystem [4,5]—in which changes in fire recurrence or intensity due to human impact can be avoided in order to maintain the ecosystem steady state.

In the Canary Islands, fires are recurrent in pine forests, although they seldom occur in the same place more than once within a 20-year period [6]. A 15-year study on fire impact in the Canary Islands revealed that fire is not pernicious for natural ecological processes $[7,8]$.

Fire has, for a long time, been an important subject of debate and a constant source of paradoxes; these arise from the apparent contradiction between its controlled use in everyday life to its threats to life and property as uncontrolled wildfires. One such contradiction and one of the most disruptive elements of ecological processes with respect to fire ecology is fire suppression specifically applied in non-commercial protected forest areas. The paradox is that "natural" fires burn a small number of 
hectares yearly; however, with current fire management, all fire is suppressed for years when possible. After 10-15 years (mainly enhanced by biomass accumulation, increase of fire-prone plant species, greater vertical biomass continuity, and appropriate weather conditions, all of which determine higher fire risk, both in terms of flammability and combustibility), catastrophic forest fires ( $>1000 \mathrm{ha}$ ) can burn in one single event, resulting in a similar number of hectares as would have burned naturally over that period $[9,10]$ and endangering properties and local population.

In this study, we collected information, provided by the government of the Canary Islands, on the number of fires and surface area burned in the last 50 years. Our hypothesis is that, in the last 50 years, the pattern of forest fires in the Canary Islands follows a fire paradox model (Figure 1) of fire recurrence, due to an accumulation of biomass that causes a steady increase in fire risk and subsequent wildfire damage leading to larger and more intense burned areas.

\section{Fire Paradox}

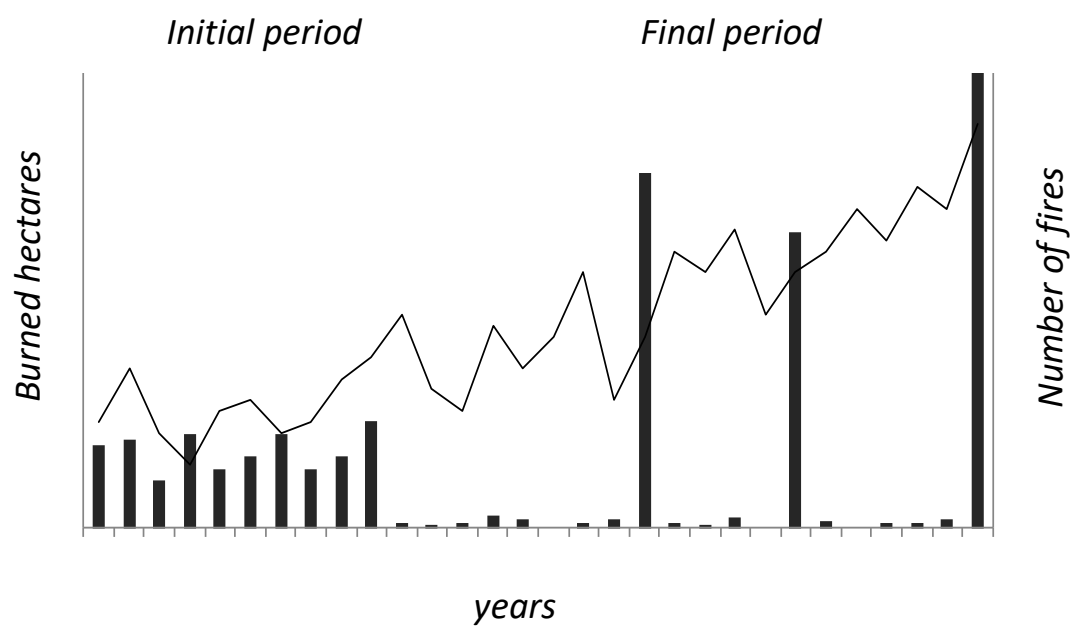

Figure 1. Conceptual model of forest fire patterns in developed and developing countries in the last five decades (bars are total surface hectares burned and the line indicates the number of fires) that follows the fire paradox hypothesis. Modified from the article by García-Domínguez (2010) [11].

\section{Materials and Methods}

\subsection{Study Site}

The natural distribution range of the Canarian pine forest (Figure 2) includes low-altitudinal sub-desert pine forest (almost at sea level) with less than $250 \mathrm{~mm}$ of rain per year, dry pine forests on southern slopes ( 350 to $500 \mathrm{~mm}$ of rain; $400 \mathrm{~m}$ altitude), sub-tropical cloud forests with more than $600 \mathrm{~mm}$ of rain per year (plus high throughfall due to mist capture), and high mountain stands reaching the timberline (1700 to $2100 \mathrm{~m}$ of altitude; $<300 \mathrm{~mm}$ of rain), where frosts and snow occur in the winter. Pine forest surface areas range from 18 ha on the island of La Gomera or 2300 ha on El Hierro to 33,309 ha on the island of Gran Canaria (Figure 2). The dominant shrub species are Erica arborea, Adenocarpus viscosus, and Chamaecytisus proliferus. A high number of annual and ruderal species are present, especially in the plots close to trails or those affected by other disturbances [12].

The influence of wet trade winds from the northeast determines the different conditions, characteristic of the exposed and sheltered slopes on each island. In addition, annual rainfall increases from southeast to northwest, resulting in differences among the islands themselves (Gran Canaria is much drier than La Palma). All soils are of volcanic origin and, with the exception of recent volcanic soils, their evolution is closely related to climatic conditions. 


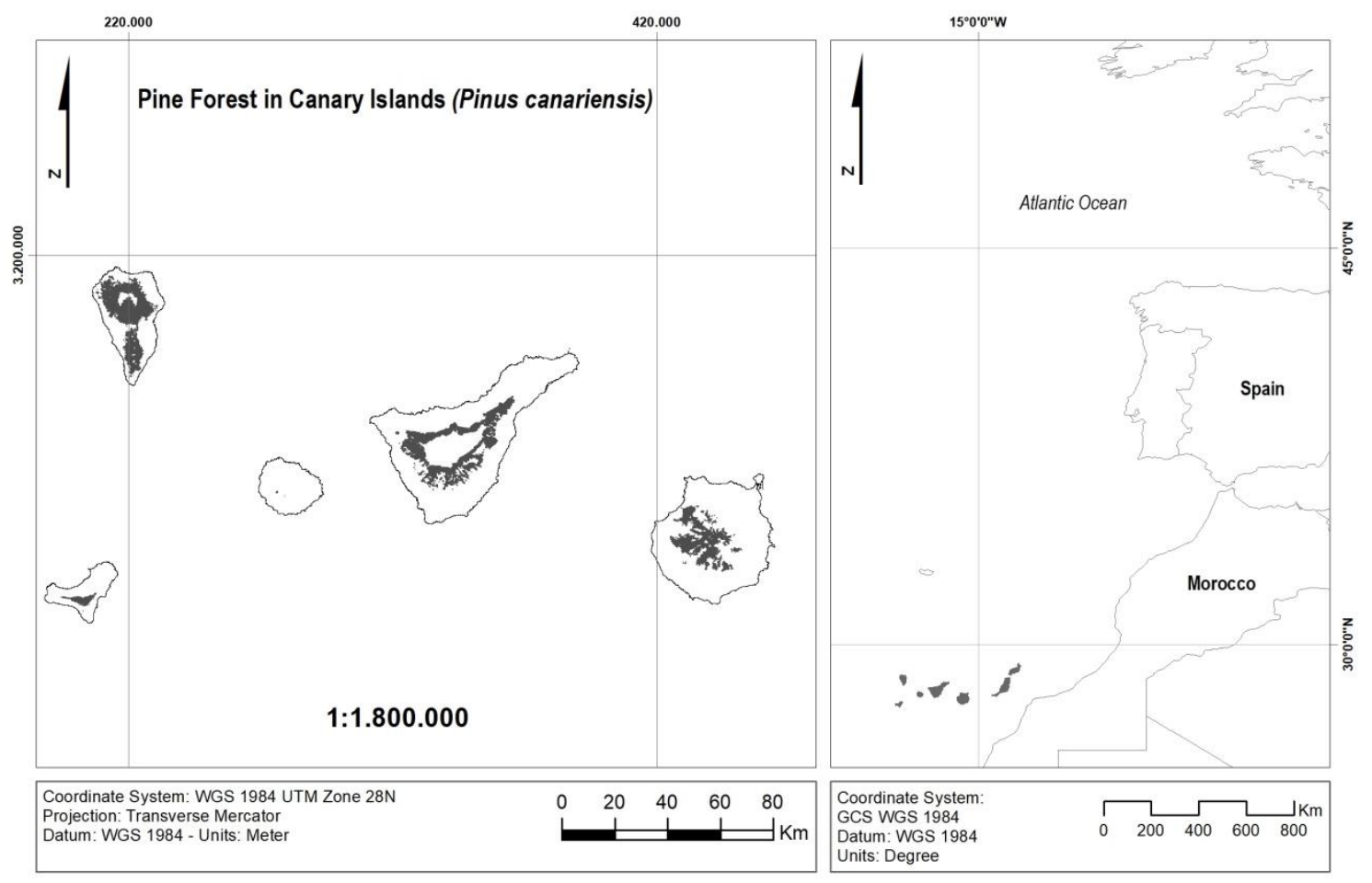

Figure 2. The Canary Islands and surface area of pine forest on the different islands with this forest stand.

\subsection{Data and Methods}

We collected information on forest fires for the entire Canary Islands archipelago from 1968-2017. The statistical information from these years is reliable and offers a period long enough to reveal evidence of the fire paradox hypothesis proposed in the introduction. Fires occurred mainly in pine forest and associated shrubland vegetation located under or surrounding the stand. Since 1968, the fires were accurately mapped and information was collected from all the official information on the webpage of the autonomous government of the Canary Islands (http:/ / www.gobiernodecanarias.org/istac/). The latest information about forest fires that follows the same methodology (years 2016 and 2017) was obtained from the database of the Ministry of Agriculture of the government of Spain (http: //www.mapama.gob.es/es/desarrollo-rural/estadisticas/Incendios_default.aspx).

We statistically and graphically described the information collected. In addition, we graphically represented the number of years per decade in which forest fire extensions were over 1000 ha. Also, differences of surface area burned per year among decades were analyzed using the Kruskal-Wallis test $(p<0.05)$. If significant differences were found, we used post hoc nonparametric Tukey tests.

\section{Results and Discussion}

The results of the information collected are presented in Figure 3. Compared to Figure 1, it is possible to establish that the Canary Islands are trapped in a fire paradox, with evidence of an increase in catastrophic fires (>1000 ha) occurring in the last 15 years. The real data represented graphically also showed similarities to the graphic model. The number of years with forest fires over 1000 ha per decade increased from two to five years in the last 50 years (Figure 4), and the years where over 7000 ha of forests burned all occurred in the last decade, except for 1983 (Figure 3). In spite of the increase of large fires, surface area burned/year per decade did not increase significantly $\left(\chi^{2}=3.48, k=5\right.$, non-significant). 


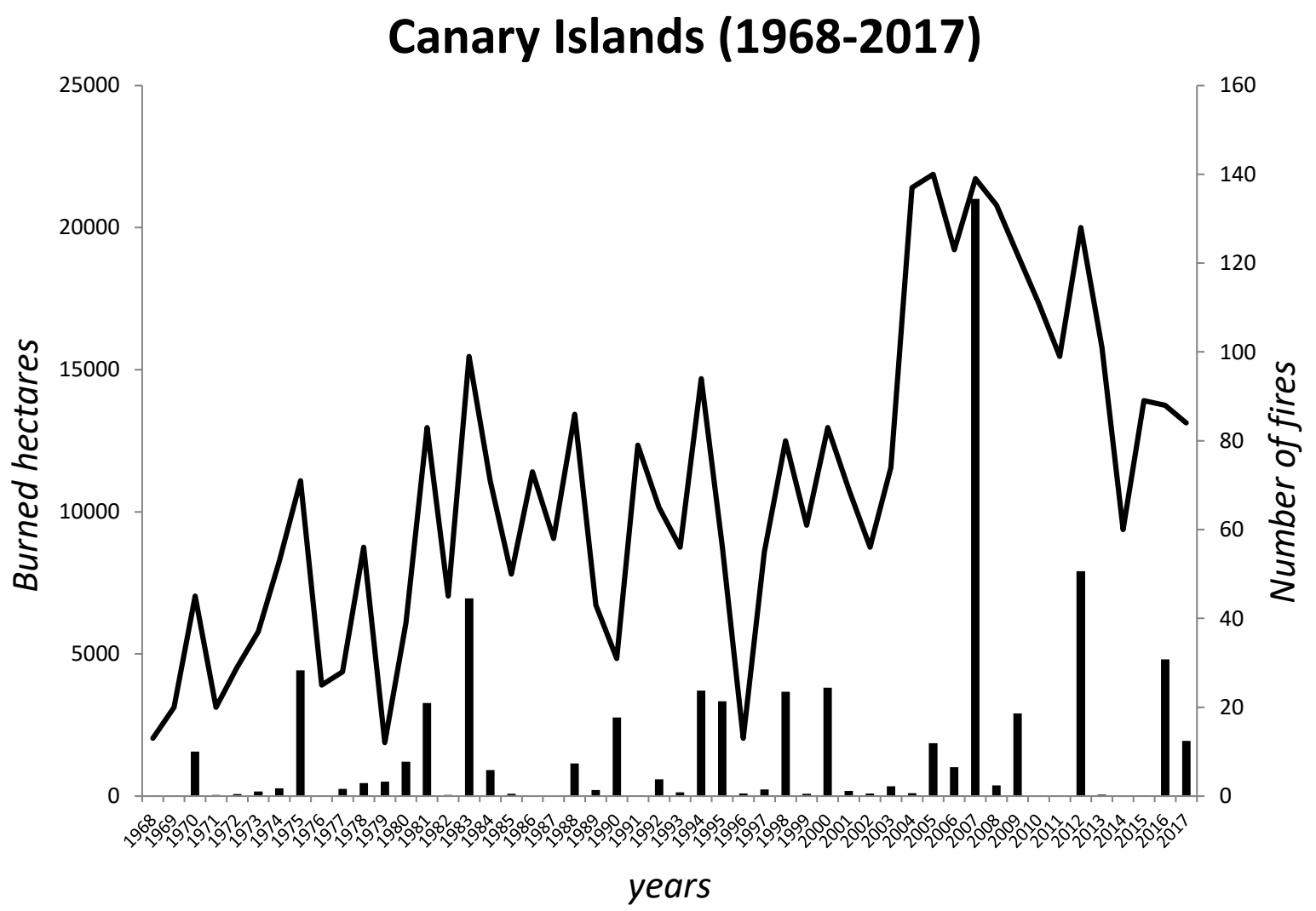

Figure 3. Information on the number of fires (line) and total surface hectares burned (bars) for the Canary Islands (information provided by the government of the Canary Islands-Vicenconsejería de Política Territorial y Medio Ambiente and Ministerio de Agricultura del Gobierno de España).

\# years with forest fires over 1000 hectares

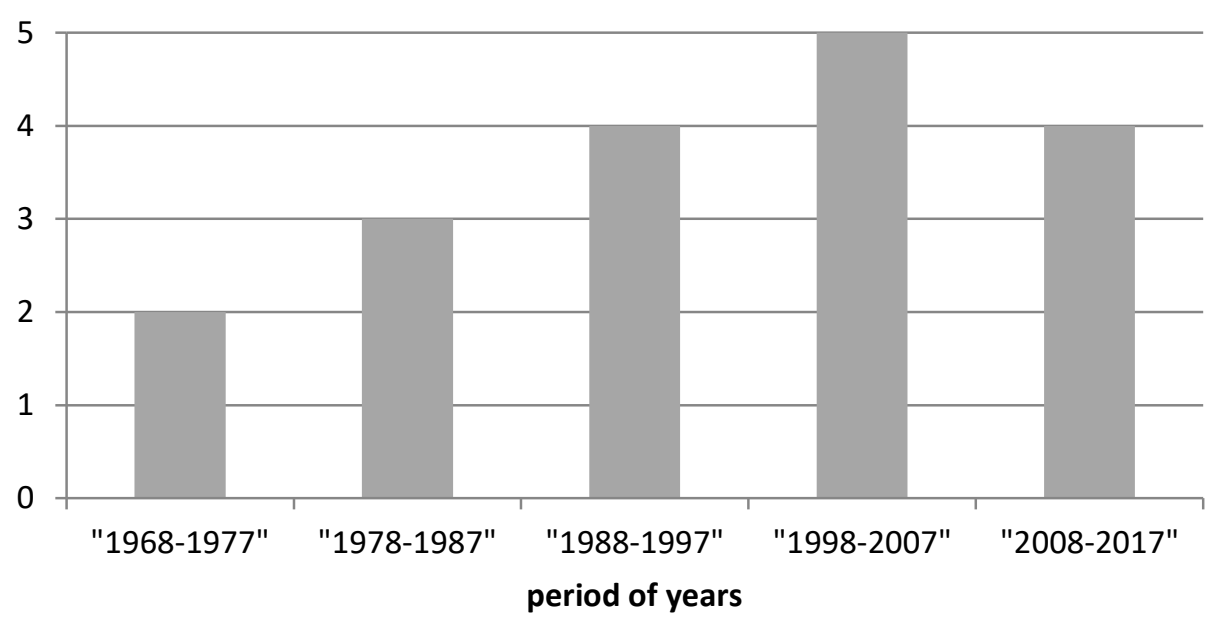

Figure 4. Number of years per decade with forest fire extensions over 1000 ha.

From this information, we can speculate, among other causes, that long periods of fire suppression occurred. This suppression is mainly due to forest fragmentation and an increase in anthropogenic corridors that restrict fire progression (both of them avoid the progression of fire as used to happen in native and well-conserved stands). There was also an improvement in effectiveness of forest fire fighters (especially since the end of the 1990s with the creation of professional groups: PRESA (Firefighters unit of the island of Gran Canria), UME (Military Unit of Emergencies), and BRIFOR (Firefighters unit of the island of Tenerie, among others; before that, fire extinction work relied on groups of volunteers with a complete lack of preparation). However, these longer periods of fire suppression 
resulted in recurrently more catastrophic (more difficult to control, with more damage to properties or even harm to humans) and larger individual surface forest fires. The increase in population, gross domestic product, and tourist visitors [13] in the last seven decades can be considered elements that also contributed to these forest patterns (through building of infrastructures and landscape change producing fragmentation, increase in number of fires, long period of suppression, etc.). Moreover, although climate change can be considered one aspect that reinforces this pattern of forest fires, average temperatures on the island of Tenerife (as an indicator of temperature changes for the rest of the archipelago) increased by around 0.6 degrees in the last 70 years [14], in addition to a lack of extreme weather events, such as droughts or big floods. Because all of this, the contribution of weather to the forest fire pattern cannot be considered different this decade than to the previous one. Also, flammability did not change significantly in the last decades, as there were no big changes in landscape use, as reported by the administration (opendata.sitcan.es). The lack of change in this important process affecting the forest patterns resulted in no significant changes in the archipelago. However, there was no change in forest structure, leaving the "fire paradox" as one of the explanations of this pattern, although it is true that an increase of $0.25^{\circ} \mathrm{C}$ in temperature [13] since the decade of the 1990s with respect to the new century may have had an influence on this pattern. It is also necessary to highlight that the number of droughts did not increase with respect to other periods before 1980 (www.aemet.es).

Some studies of this plant community revealed the positive effect of forest fires in ecological processes such as regeneration (increase in germination), litter nutrient mineralization, increase in native species richness, and favoring native species composition $[4,8,15]$ or even control of exotic species $[16,17]$. Canarian pine forest stands were subjected to long-term degradation, especially since the European colonization of the islands [18]. Despite being the most extensive forest community of the islands, only $54 \%$ of the Canarian pine forest $(60,678 \mathrm{ha})$ persists currently in its natural range and is highly fragmented [19]. Thus, a reduction in the fire rate can be considered as another cause of degradation of these forest stands. This situation is becoming more common, also in other areas like the southern states of the United States of America (USA) or Portugal, where fires are becoming more intense, despite burning fewer ha $[10,20]$.

Based on the information provided, we argue that prescribed burning can operate not only as a management tool for fire prevention, but also as a tool for achieving ecological restoration objectives. Therefore, such a change in fire management practices should be implemented, encouraging active management through prescribed burning, as, from an ecological perspective, the Canarian pine forest has the ability to recover from fire effects in the short term. In fact, several studies demonstrated the positive or null impact of prescribed burning in ecological forest processes with respect to plant communities, favoring native plant communities, as well as enhancing germination of native pine and native micro-invertebrate species composition and richness [21,22].

Knowing that disturbances accelerate ecosystem succession and dynamics [23-25], we suggest that the regular occurrence of fires, based also on these results and previous studies [8] (less than 20 years ago), as internal ecosystem processes, will favor and accelerate the evolution of the pine forest toward a more natural system in the case of plantations and will help maintain ecological processes in the case of natural stands. Our recommendation, therefore, is that local authorities should consider prescribed burning as a valuable tool in order to avoid catastrophic fires that endanger property and even human lives (e.g., the recent fires on Gran Canaria in 2013 and La Gomera and Tenerife in 2012). Moreover, this would encourage active forest management through prescribed burning; since, from an ecological point, Canarian pine forests have the ability to recover from fire effects in the short term, this would have a positive impact on diversity and ecological processes.

Funding: This research received no external funding.

Acknowledgments: We thank the personnel and administration of the "Cabildo de Tenerife" and "Cabildo de Tenerife" for the support to conduct this study. We appreciate the criticism and suggestions that highly improved the quality of this manuscript provided by two anonymous reviewers. 
Conflicts of Interest: The authors declare no conflict of interest.

\section{References}

1. Pickett, S.T.A.; White, P.S. The Ecology of Natural Disturbance and Patch Dynamics; Academic Press: New York, NY, USA, 1985; ISBN 9780125545204.

2. Rowe, N.P.; Jones, T.P. Devonian charcoal. Palaeogeogr. Palaeoclimatol. Palaeoecol. 2000, 164, $347-354$. [CrossRef]

3. Latham, D.J.; Williams, E. Lightning and forest fires. In Forest Fires, Behavior and Ecological Effects; Johnson, E.A., Miyanishi, K., Eds.; Academic Press: New York, NY, USA, 2011; pp. 375-418, ISBN 978-0123866608.

4. Arévalo, J.R.; Álvarez, P.; Narvaez, N.; Walker, K. The effects of fire in the regeneration of a Quercus douglasii stand in Quail Ridge Reserve, Berryessa Valley (California). J. For. Res. 2009, 14, 81-87. [CrossRef]

5. Arno, S.F.; Fiedler, C.E. Mimicking Nature's Fire: Restoring Fire-Prone Forests in the West; Island Press: Washington, DC, USA, 2005; ISBN 9781559631433.

6. Del Arco, M.J.; Pérez, P.L.; Rodríguez, O.; Salas, M.; Wildpret, W. Cartographic atlas of the Canarian Pine Stand II: Tenerife [Atlas Cartográfico de los Pinares Canarios II: Tenerife]; Viceconsejería de Medio Ambiente y Conservación de la Naturaleza, Consejería de Política Territorial: Gobierno de Canarias, Spain, 1992; ISBN 8460604403. (In Spanish)

7. Höllermann, P. The impact of fire in Canarian ecosystems 1983-1998. Erdkunde 2000, 54, 70-75. [CrossRef]

8. Arévalo, J.R.; Fernández-Palacios, J.M.; Jiménez, M.J.; Gil, P. The effect of fire intensity on the understory species composition of two Pinus canariensis reforested stands in Tenerife (Canary Islands). For. Ecol. Manag. 2001, 148, 21-29. [CrossRef]

9. Silva, J.S.; Rego, F.; Fernandes, P.; Rigolot, E. Towards Integrated Fire Management: Outcomes of the European Project Fire Paradox; European Forest Institute: Joensuu, Finland, 2010.

10. Fernandes, P.M.; Rego, F.C.; Rigolot, E. The FIRE PARADOX project: Towards science-based fire management in Europe. For. Ecol. Manag. 2011, 261, 2177-2178. [CrossRef]

11. García-Domínguez, C. Fire Impact on the Cological Processes and Biodiversity Maintainance in the Canarian Pine Plantations of Pinus canariensis [Impacto del Fuego en los Procesos Ecológicos Relacionados con el Mantenimiento de la Diversidad en Pinares Repoblados de Pinus canariensis]. Ph.D. Thesis, University of La Laguna, La Laguna, Spain, 2010.

12. Ceballos, L.; Ortuño, F. Vegetation and Forest Plants of the Occidental Canarian Islands [Vegetación y flora forestal de las Canarias Occidentales], 2th ed.; Cabildo Insular de Tenerife: Santa Cruz de Tenerife, Spain, 1974; ISBN 8450016665. (In Spanish)

13. Arévalo, J.R.; Esquivel, J.L.; Ojeda-Land, E. Socioeconomics and temperature anomalies: Drivers of introduced and native plant species composition and richness in the Canary Islands. Bot. Sci. 2017, 95, 1-20. [CrossRef]

14. Martín, J.L.; Bethencourt, J.; Cuevas, E. Assessment of global warming in the Canary Islands. Trends since 1944 in the maximum and minimum annual temperatures on the island of Tenerife (Spain). Clim. Chang. 2012, 114, 343-355. [CrossRef]

15. Arévalo, J.R.; Fernández-Lugo, S.; Naranjo, A.; Salas, M.; Ruíz, R.; Ramos, R.; Moreno, M. Post-fire recovery of an endemic Canarian pine forest. Int. J. Wildl. Fire 2014, 23, 403-409. [CrossRef]

16. Arévalo, J.R.; Naranjo, A.; Salas, M. Regeneration in a mixed stand of native Pinus canariensis and introduce Pinus pinea species. Acta Oecol. 2005, 28, 87-94. [CrossRef]

17. Arévalo, J.R.; Fernández-Palacios, J.M. Gradient analysis of exotic Pinus radiata plantations and potential restoration of natural vegetation in Tenerife, Canary Islands (Spain). Acta Oecol. 2005, 27, 1-8. [CrossRef]

18. Parsons, J.J. Human influences on the pine and Laurel Forests of the Canary Islands. Geogr. Rev. 1981, 71, 253-271. [CrossRef]

19. Delgado, J.D. Road Border Effect on the Laurel Forest and Pine Forest of Tenerife (Canary Islands) [Efectos de Borde de las Carreteras en la Laurisilva y Pinar de Tenerife (Islas Canarias)]. Ph.D. Thesis, University of La Laguna, La Laguna, Spain, 2003. (In Spanish)

20. Pechony, O.; Shindell, D.T. Driving forces of global wildfires over the past millennium and the forthcoming century. Proc. Natl. Acad. Sci. USA 2010, 107, 19167-19170. [CrossRef] [PubMed] 
21. Arévalo, J.R.; Fernández-Lugo, S.; Afonso, V.; Grillo, F.; Naranjo, A. Effects of prescribed fire on understory vegetation in a canarian pine forest stand (Canary Islands, Spain). Bull. USAMV Ser. Agric. 2014, 71, 133-136. [CrossRef]

22. García-Domínguez, C.; Arévalo, J.R.; Calvo, L. Short-term effects of low-intensity prescribed fire on ground-dwelling invertebrates in a Canarian pine Forest. For. Syst. 2010, 19, 112-120. [CrossRef]

23. Lorimer, C.G. Age structure and disturbance history of a Southern Appalachian virgin forest. Ecology 1980, 61, 1169-1184. [CrossRef]

24. Abrams, M.D.; Scott, M.L. Disturbance-mediated accelerated succession in two Michigan forest types. For. Sci. $1989,35,42-49$.

25. DeCoster, J.K. Impacts of Tornados and Hurricanes on the Community Structure and Dynamics of North and South Carolina Forests. Ph.D. Dissertation, University of North Carolina, Chapel Hill, NC, USA, 1996.

(c) 2018 by the authors. Licensee MDPI, Basel, Switzerland. This article is an open access article distributed under the terms and conditions of the Creative Commons Attribution (CC BY) license (http://creativecommons.org/licenses/by/4.0/). 